\title{
Comparison of agricultural mechanization indicators between western and eastern region of Uttar Pradesh, India
}

\section{Tarun Kumar Maheshwari and Ashok Tripathi}

Received : 26.07.2019; Revised : 21.08.2019; Accepted : 07.09.2019

See end of the Paper for authors' affiliation

Correspondence to :

Tarun Kumar Maheshwari

Farm Machinery and Power Engineering, Vaugh School of Agricultural Engineering Technology, Sam Higginbottom University of Agriculture, Technology and Sciences, Allahabad (U.P.) India Email : maheshwari_tk@ yahoo.com
- ABSTRACT : Uttar Pradesh (UP) is the most populous state in India with 16.16 per cent of India's total population (Census, 2011). In terms of area, it is the fourth largest state in the country. The western region is characterized as the food and sugar basket of Uttar Pradesh. The western region was far ahead in adoption of improved technology as compared to other regions in Uttar Pradesh. Eastern region of Uttar Pradesh is flood prone. Poverty is acute in this region. Therefore, household food security is the primary concern of the farm households in this region. Farm mechanization is essential for sustaining agricultural growth, especially in the context of diminishing agricultural labour. However, large communities of small and marginal farmers are still not in a position to take full benefit of farm mechanization. After selection of variables, a questionnaire was prepared to collect primary data from each agro-climatic zone of western and eastern region. In western region primary data were collected from 200 farmers from 20 villages of 5 districts and in eastern region 3 districts out of 27 districts were taken for the study and primary data were collected of 180 farmers from 18 villages in 3 districts. The mechanization indicators were higher in western region in comparison to eastern region but human energy was more in eastern region than western region. The average value of mechanization index, power availability, cropping intensity, irrigation intensity, annual farmers income, annual input cost, human energy mechanical energy, total energy in western region and eastern region of Uttar Pradesh were $0.958,3.98 \mathrm{~kW} / \mathrm{ha}, 176 \mathrm{per}$ cent, 176 per cent, Rs. 263538, Rs.45609, $63.73 \mathrm{kWh} / \mathrm{ha}, 1132 \mathrm{kWh} / \mathrm{ha}$ and $1203 \mathrm{kWh} / \mathrm{ha}, 0.951,2.61$ $\mathrm{kW} / \mathrm{ha}, 160.42$ per cent, 160.42 per cent, Rs. 177125 , Rs. $49586,81.98 \mathrm{kWh} / \mathrm{ha}, 655.49 \mathrm{kWh} / \mathrm{ha}$ and $735.94 \mathrm{kWh} / \mathrm{ha}$, respectively. Similarly, degree of mechanization was also higher in western region in comparison eastern region in most of unit operations.

- KEY WORDS : Mechanization index, Farm power, Degree of mechanization, Cropping intensity, Human energy, Mechanical energy, Total energy

- HOW TO CITE THIS PAPER : Maheshwari, Tarun Kumar and Tripathi, Ashok (2019). Comparison of agricultural mechanization indicators between Western and Eastern region of Uttar Pradesh, India. Internat. J. Agric. Engg., 12(2) : 208-216, DOI: 10.15740/HAS/IJAE/12.2/208-216. Copyright@2019: Hind Agri-Horticultural Society. 